\section{Graft Compatibility Between Peach Cultivars and Prunus Rootstocks}

\author{
Olfa Zarrouk, ${ }^{1}$ Yolanda Gogorcena, and Maria Angeles Moreno \\ Department of Pomology, Estacion Experimental de Aula Dei (CSIC), \\ Apartado 202, 50080 Zaragoza, Spain
}

\author{
Jorge Pinochet \\ Agromillora Catalana S.A., C/El Rebato s/n, 08739 Subirats (Barcelona), Spain
}

Additional index words. nectarine, SPAD value, stem circumference, plum rootstocks, incompatibility

\begin{abstract}
Trials were established at Aula Dei Experimental Station (EEAD-CSIC, Zaragoza, Spain) to assess graft compatibility between peach cultivars [Prunus persica (L.) Batsch] and new Prunus spp. rootstocks or selections. Peach cvs. 'Catherina' and 'Tebana' and nectarine cvs. 'Big Top' and 'Summergrand' were grafted on peach seedlings, plum rootstocks, almond $x$ peach hybrids, and other interspecific rootstocks. Part of the evaluated material belongs to the EEAD-CSIC selection program, which has showed good adaptation to Mediterranean growing conditions. Other rootstocks such as Bruce, Evrica, Hiawatha, Ishtara, Tetra, and Krymsk-1 have been recently introduced in Spain. A peach and a plum source, GF 677 and Adesoto 101, respectively, were used as compatible reference rootstocks. Both are widely used for peach and nectarine production in the Mediterranean area.
\end{abstract}

Most almond $\mathrm{x}$ peach hybrids and slowgrowing plums (i.e., P. domestica and $P$. insititia plums like 'Pollizo de Murcia') were graft-compatible with all tested cultivars. However, in the case of fast-growing plums ( $P$. cerasifera and interspecific hybrids with this species), performance differed substantially depending on the evaluated genotype. Several levels of response to graft incompatibility were found for both "localized" and "translocated" types of incompatibility, and some physiological aspects of graft incompatibility are discussed.

Commercial peach trees [Prunus persica (L.) Batsch] are usually composed of two genetically different parts: a scion and a rootstock. The availability of peach rootstocks largely depends on the various species or interspecific hybrids that can be used with peach as a scion. In the Mediterranean area (representing $35 \%$ of the peach world production; FAOSTAT, 2006), almond $x$ peach hybrids rootstocks are widely used because of some desirable characteristics such as tolerance to drought and lime-induced $\mathrm{Fe}$ chlorosis (Socias i Company et al., 1995).

\footnotetext{
Received for publication 23 May 2006. Accepted for publication 24 June 2006. Financial support was provided by Comisión Interministerial de Ciencia y Tecnologia (AGL2002-4219 and AGL2005-05533 projects) and by a fellowship granted to O. Zarrouk from the Agencia Española de Cooperación Internacional (AECI). We gratefully acknowledge Victoria Fernandez for revising the manuscript and J. Aparicio and P. Sanchez of the department of Pomology for their assistance in orchard management

${ }^{1}$ To whom reprint requests should be addressed; e-mail z.olfa@eead.csic.es.
}

Nevertheless, the highly successful almond x peach hybrid rootstock GF 677 is also extremely vigorous (Wertheim and Webster, 2005; Zarrouk et al., 2005) and relatively susceptible to nematodes, compact soils, and waterlogging (Gómez Aparisi et al., 2001; Okie, 1987). Because control of tree vigor is becoming increasingly important for peach production, plum rootstocks and inter- or intraspecific plum hybrid rootstocks are used with peach cultivars. Indeed, plum rootstocks are generally less vigorous, more tolerant to waterlogging (Nasr et al., 1977), resistant to root-knot nematodes (Moreno et al., 1995a; 1995b; Pinochet et al., 1999), and also provide the possibility to overcome replanting problems (Nicotra and Moser, 1997) as compared with almond $x$ peach hybrid rootstocks.

However, the limiting factor for the widespread use of some Prunus spp. for peach production is the lack of commercial rootstocks having a wide range of compatibility with various cultivars (Okie, 1987). For a composite fruit tree to remain healthy, the rootstock and the scion should intimately unite, providing a viable system for the uptake and translocation of water, minerals, assimilates, and hormones throughout the entire lifespan of the plant (Wertheim and Webster, 2005). Graft incompatibility leads to poor health, breakage at the graft union, and premature death or failure of the graft combination to form a strong and lasting functional union.

The mechanisms by which incompatibility is caused and expressed remain unclear and several hypotheses have been made (Pina and Errea, 2005). Conversely, previous studies (Mosse, 1962) described "translocated" graft incompatibility on peach when it was grafted on several plum rootstocks. Incompatibility is usually expressed during the first year of scion growth in the form of tree growth cessation and premature defoliation with leaf discoloration (yellowing or bronzing) (Herrero, 1951). "Translocated" incompatibility in peach/plum combinations was associated with both functional and biochemical alterations at the graft interface (Moing and Carde, 1988; Moing et al., 1987), inducing a carbohydrate blockage in the scion above the graft union (Breen, 1975; Moing et al., 1987; Moing and Gaudillère, 1992). Nevertheless, incompatibility symptoms may occur at a later stage of development (Moreno et al., 1993), and the presence of some biochemical alterations across the graft union of Prunus may lead to a slight and delayed incompatibility as has been described in cherry by Treutter and Feucht (1991). Moreover, peach/plum combinations can exhibit symptoms of "localized" incompatibility (Salesses and Bonnet, 1992). The occurrence of "localized" incompatibility is characterized by anatomic irregularities at the union interface (Moreno et al., 1995a) with breaks in cambial and vascular continuity patterns (Mosse, 1962) and poor vascular connections (Errea, 2001) inducing mechanical weakness of the union, which may break after some years (Herrero, 1951), subsequently leading to major economic losses.

These problems make rootstock selection difficult, because commercialization of new rootstocks requires preliminary evaluation of possible incompatibility reactions. Additionally, incompatibility can be positively correlated with warm climates by increasing the activity of some biochemical substances related to graft incompatibility (Gur et al., 1968). This might result in exacerbated graft incompatibility when some rootstocks selected in cold areas are used in warm climate regions.

The objective of this study was to test the compatibility behavior of several Prunus rootstocks with peach and nectarine scions as a preliminary step to their transfer to commercial peach production orchards.

A rootstock screening experiment was carried out to identify and determine the graft compatibility of Prunus rootstocks in the process of selection and to establish comparisons in terms of compatibility with new commercial rootstocks of European, American, and Russian origins, recently introduced into the European market. The graft compatibility of peach (cvs. Catherina and Tebana) and nectarine (cvs. Big Top and Summergrand) scions with 44 different Prunus rootstocks was assessed in nurseries and orchards of Aula Dei Experimental Station (EEADCSIC). Similarly, some physiological aspects of incompatibility expression were studied to search for indicators associated with graft incompatibility.

\section{Materials and Methods}

\section{Plant material}

A 3.5-year graft incompatibility study was carried out at the Aula Dei Experimental 
Station. Trials were established on a calcareous soil containing $29 \%$ to $30 \%$ total calcium carbonate, $7.4 \%$ to $7.6 \%$ active lime, and water $\mathrm{pH} 8.0$ with a clay-loam texture. Peach and nectarine cultivars were T-budded in situ in summer of each year from 2000 to 2002 .

'Big Top' nectarine, 'Catherina' and 'Tebana' peach cultivars were grafted on almond $x$ peach hybrids and 'Pollizo de Murcia' plum rootstocks. 'Big Top' was also grafted on interspecific hybrid plums. 'Summergrand' nectarine was used as an indicator cultivar for restrictive compatibility (Moreno et al., 1993), and it was grafted on most rootstocks in this study. In all trials, the almond $x$ peach hybrid rootstock GF 677 was used as reference because it is commonly used in Mediterranean countries, and it is graft-compatible with all peach cultivars. Some plum rootstocks such as Adesoto 101 (Moreno et al., 1995b), Damas GF 1869, and Marianna 2624 were also used for comparison purposes.

The different rootstock species used in this investigation were obtained from the rootstock selection program of the Aula Dei Experimental Station and from Agromillora Catalana S.A. nursery (Barcelona, Spain). For practical purposes, rootstock genotypes were divided into four groups as shown in Table 1.

Each scion/rootstock combination was replicated 15 to 30 times depending on the availability of plant material. Some combinations suffered losses after 3 years of field testing, mainly as a result of the occurrence of incompatibilities. Ten replicates per combination were considered the minimum acceptable for assessment.

\section{"Translocated" incompatibility study}

The level of compatibility-incompatibility was determined during the first 2 years after grafting by visual diagnosis of the possible causes of the "translocated" type of incompatibility in the nursery, e.g., leaf and wood yellowing and reddening, defoliation, tree vigor reduction, and death (Moreno et al., 1993). Moreover, a determination of leaf chlorophyll concentration using a SPAD $502 \mathrm{~m}$ (Minolta Co., Osaka, Japan) was made each year on 1-year-old trees from the end of June to the beginning of July. This procedure was used as a potential tool to estimate the rate of "translocated" graft incompatibility. Measurements were made on fully expanded leaves of 10 trees per combination selected from the middle of the cultivar shoot.

\section{"Localized" incompatibility study}

When trees were still alive, in the second and third year after grafting, anatomic examination of unions ("localized" incompatibility) was carried out. Graft unions were sawed by a radial-longitudinal plane according to Mosse and Herrero (1951). The visual rating of "localized" graft incompatibility was classified as follows:

Category A = Perfect unions. The line of union in bark and wood was hardly visible.

Category $\mathrm{B}=$ Good unions. The bark and wood were continuous although the line of union in the wood was often clearly distinguished by excessive ray formation.

Category $\mathrm{C}=$ Unions with discontinuities in the bark. The bark tissues of rootstock and scion were separated by a dark brown layer of corky appearance.

Category $\mathrm{D}=$ Unions showing vascular and wood discontinuities. The woody tissues of rootstock and scion were separated in many places by clusters of living, nonlignified parenchyma. Bark tissues were generally as category $\mathrm{C}$.

Category $\mathrm{E}=$ Observed breakage of the tree at the graft union in the nursery.

Also, at the time of internal examination, stem circumferences $\approx 5 \mathrm{~cm}$ above and below the graft union were measured. This method enabled searching for correlations between growth characteristics and compatibility-incompatibility symptoms.

\section{Analysis of data}

Data were evaluated by analysis of variance with SPSS 13.0 (SPSS, Chicago). Analysis of variance was made by analysis of variance at $P \leq 0.05$ and was used to assess the significance of stem circumference and SPAD values. Mean separation was determined by Duncan's test and results shown correspond to mean values. To establish correlations between incompatibility symptoms and stem circumference, the following scale was designed: level 0 to compatible grafts, 1 to the presence of only one incompatibility type, and 2 to the coexistence of both incompatibilities.

\section{Results and Discussion}

\section{"Translocated" incompatibility}

As expected, all peach and nectarine trees on Euamygdalus subgenus rootstocks (Table 1) showed good graft compatibility (Table 2 ). Similarly, and with the exception of PP-1 and PAC 952, most graft combinations were compatible when peach cultivars were grafted on slow-growing plums (Table 1). This was the case of peach and nectarine cultivars used in this study when they were grafted on 'Pollizo de Murcia' plums currently under selection (e.g., PM $44 \mathrm{AD}, \mathrm{PM}$ 95 AD, PM 101 AD, PM 105 AD, PM 137 $\mathrm{AD}$, and PM $150 \mathrm{AD}$ ) and on Adesoto 101 used as a reference. Additionally, no incompatibility symptoms were observed in Big Top/St Julien GF 655-2 and in 'Summergrand'/Tetra combinations. Results concerning the latter combination are in agreement with results of previous studies, which reported good compatibility of Tetra with peach and nectarine cultivars (Nicotra and Moser, 1997).

In the fast-growing plum group (Table 1), only three Myrobalan clone rootstocks (P 2175, P 2980, and P 3293) exhibited good compatibility when they were grafted with 'Summergrand' nectarine (Table 2). This is in agreement with the findings of Salesses and Bonnet (1992) in which Myrobalan P 2175 was tested with other nectarines. The good compatibility of nectarine cultivars with some Myrobalan rootstocks support the need to investigate them with other nectarine and peach cultivars as a result of their high resistance and tolerance to some biotic and abiotic stresses as compared with other plum rootstocks (Crossa Raynaud and Audergon, 1987). In the interspecific plum group, only Hiawatha, Ishtara, Jaspi, PAC 941, and PAC 959 showed good graft compatibility with 'Summergrand' nectarine. Similar good compatibility behavior results have been previously observed with Ishtara (Reighard et al., 1997), Jaspi (Iglesias et al., 2004), and Hiawatha (Weibel et al., 2003) despite its parental $P$. besseyi background, which is generally graft-incompatible with peach cultivars (Layne, 1987). However, when nectarine cultivars were grafted on fast-growing plums and interspecific hybrids plums, "translocated" incompatibility increased. Thus, after the first season of nursery growth, all combinations of 'Summergrand' nectarine grafted on PP-1, Marianna 2624, Marianna 4001, Myrobalan 29 C, Myrobalan P 1079, Bruce, Damas GF 1869, Evrica, Krymsk-1, and Myrobalan GF 3-1 rootstocks (Table 2) showed clear symptoms of "translocated" incompatibility. The visual symptoms appeared during early and midsummer in the form of leaf yellowing, a reduction of growth, and premature defoliation. Cases of incompatibility with Evrica rootstock were predictable because two of its parents $(P$. besseyi and $P$. cerasifera) are usually known to be incompatible with peach and nectarine cultivars (Layne, 1987). Nevertheless, the incompatibility found in Krymsk-1 contrasts with previous studies carried out in South Carolina (Reighard et al., 2005). This may be the result of the differential behavior of this rootstock depending on pedologic environments and climatic conditions. We also observed the development of "translocated" or "localized" incompatibilities when Krymsk-1 rootstock was grafted with most of the 29 cultivars tested in another study (data not shown). This suggested that care should be taken in using this rootstock with commercial peach varieties in the Mediterranean area.

On the other hand, the severity of incompatibility symptoms differed between the various combinations. 'Summergrand' nectarine trees grafted on PP-1, Marianna 4001, Myrobalan 29 C, and Evrica had a healthy external bark appearance at the graft union and homogeneous vigor despite the light visual "translocated" incompatibility symptoms observed in the foliage. In this case, tree growth cessation was less acute and SPAD values were not significantly different from those of compatible trees (Fig. 1). Conversely, 'Summergrand' trees grafted on Marianna 2624, Myrobalan GF 3-1, Myrobalan P 1079, Damas GF 1869, and Miral showed premature defoliation, early growth cessation, very low SPAD values (Fig. 1), and acute leaf curl since the very first growing season (1-year-old trees). SPAD values are generally correlated with leaf chlorophyll concentration (Shi and Byrne, 1995). Its use to quantify the rate of leaf yellowing resulting 
Table 1. Rootstocks used for the peach graft compatibility study.

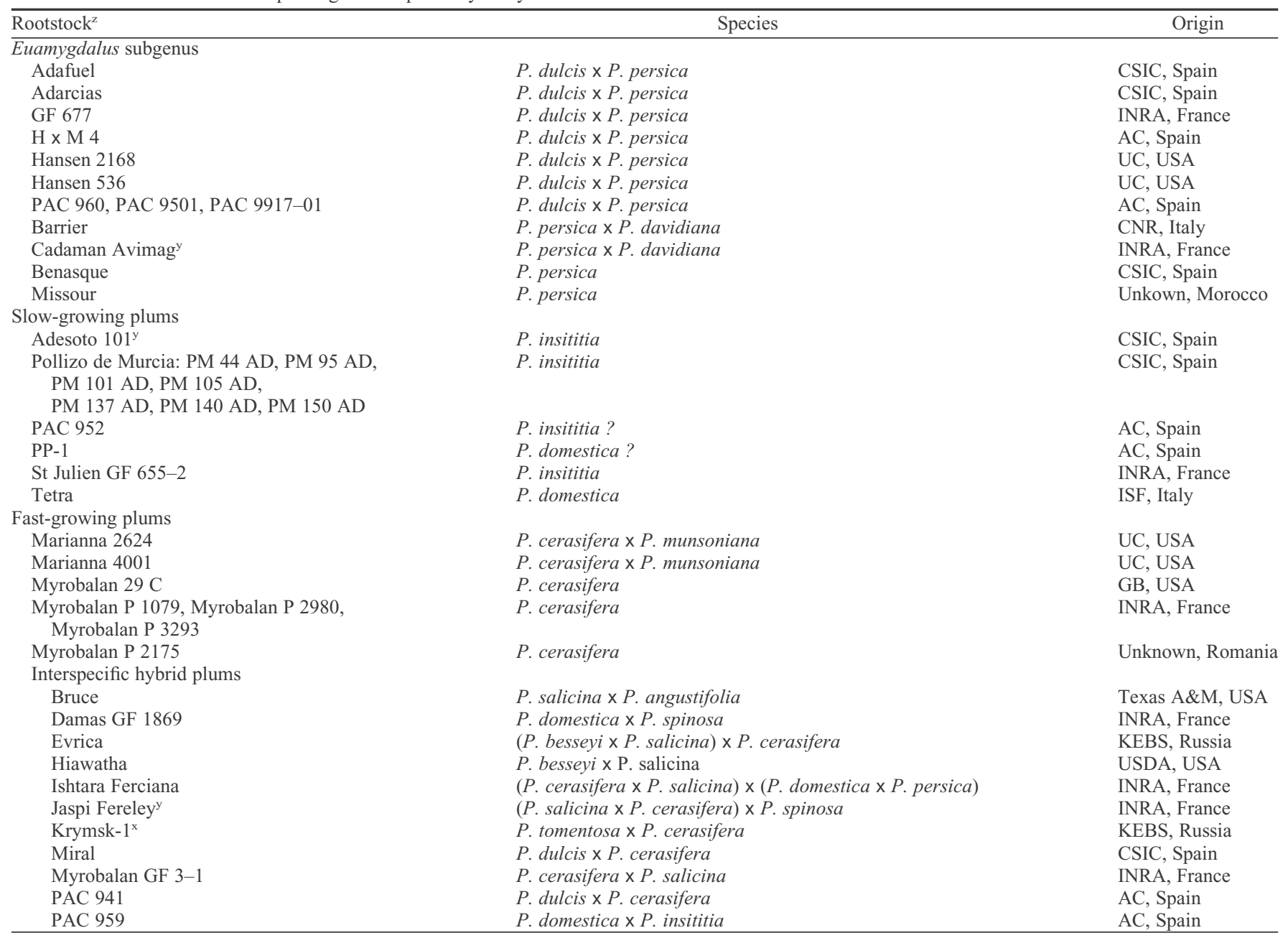

${ }^{\mathrm{z} N e x t}$ the rootstock.

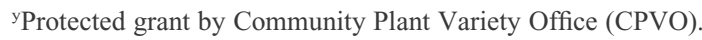

${ }^{x}$ Submitted to protection in CPVO.

AC, Agromillora Catalana S.A., private nursery, Spain; CNR, Centro Nacionale della Recerca; CSIC, Consejo Superior de Investigaciones Cientificas; INRA, Institut Nacional de la Recherche Agronomique; GB, Gregory Brother's, Calif.; ISF, Instituto Sperimentale per la Fruticultura; UC, Univ. of California; Texas A\&M, Univ. of Texas, College Station; KEBS, Krymsk Experimental Breeding Station. USDA, U.S. Dept. of Agriculture, Mandan, N.Dak.

from "translocated" incompatibility can be useful, because low SPAD values may be associated with the blockage of carbohydrate assimilation and nitrogen uptake. As the rate of shoot growth of incompatible graft declines, carbon export from the scion through the phloem to the rootstock has been reported to slow down and decrease nitrogen assimilation (Moing and Gaudillère, 1992; Moreno et al., 1994). This suggests that the rate of tissue dysfunctions (Moing and Carde, 1988) and the degree of leaf chlorosis may differ from one incompatible combination to another. This different degree of graft incompatibility was previously observed in peach grafted on different Myrobalan clones (Moreno et al., 1993, Yamaguchi et al., 2004) and may be the result of the differential sensitivity of rootstocks to poisoning substances synthesized in peach or nectarine foliage (Moing et al., 1987). The absence of incompatibility in the 'Big Top'/Damas GF 1869 combination (Table 2) contrasted with previous studies reporting severe incompati- bility between nectarine cultivars and this rootstock (Moing and Salesses, 1988). This may be explained by the different level of toxic substance synthesis in peach and nectarine cultivars (Moing et al., 1987).

\section{"Localized" incompatibility}

Like in the 'translocated' incompatibility study, all peach and nectarine trees grafted on Euamygdalus subgenus rootstocks showed good graft compatibility (Table 2). Nevertheless, in the case of the 'Summergrand'/PAC 960 combination, some gum exudation at the graft union occurred. The reason for such exudation remains unknown; however, in sweet cherry grafts, gum exudation can indicate incompatibility problems (Jänes and Pae, 2004). Anatomic evaluation of graft unions indicates "localized" incompatibility in some 2- to 3-year-old combinations with several slow-growing plum rootstocks. Graft unions with 'Catherina' and 'Tebana' cultivars on PM 140 AD (100\% for 'Tebana') rootstock were classified as "C" (Table 2), which may be considered the threshold for compatibility in practical terms. Nevertheless, trees classified within the " $\mathrm{C}$ " category can progress to an eventual "localized" incompatibility ("D" category) in the future (unpublished data). Therefore, this material should either be eliminated from the rootstock selection process for peach cultivars or be evaluated for several more years before acceptance. "Localized" incompatibility symptoms were expressed both in the form of necrosis and absence of lignified tissues in the wood graft plane and, in some cases, by the swelling of the graft union. This was the case of 'Catherina', 'Tebana', and 'Summergrand' cultivars grafted on PM 95 AD (Table 2). These cases of incompatibility with 'Pollizo de Murcia' rootstocks are uncommon. Nevertheless, because PM $95 \mathrm{AD}$ and PM $140 \mathrm{AD}$ are open-pollinated selections, they may have an incompatible parent, which could explain the results found in this study. On the other hand, "localized" incompatibility was also expressed by union breakage of some 2-year-old 
Table 2. Graft compatibility and internal examination of the graft unions between peach and nectarine cultivars and Prunus rootstocks.

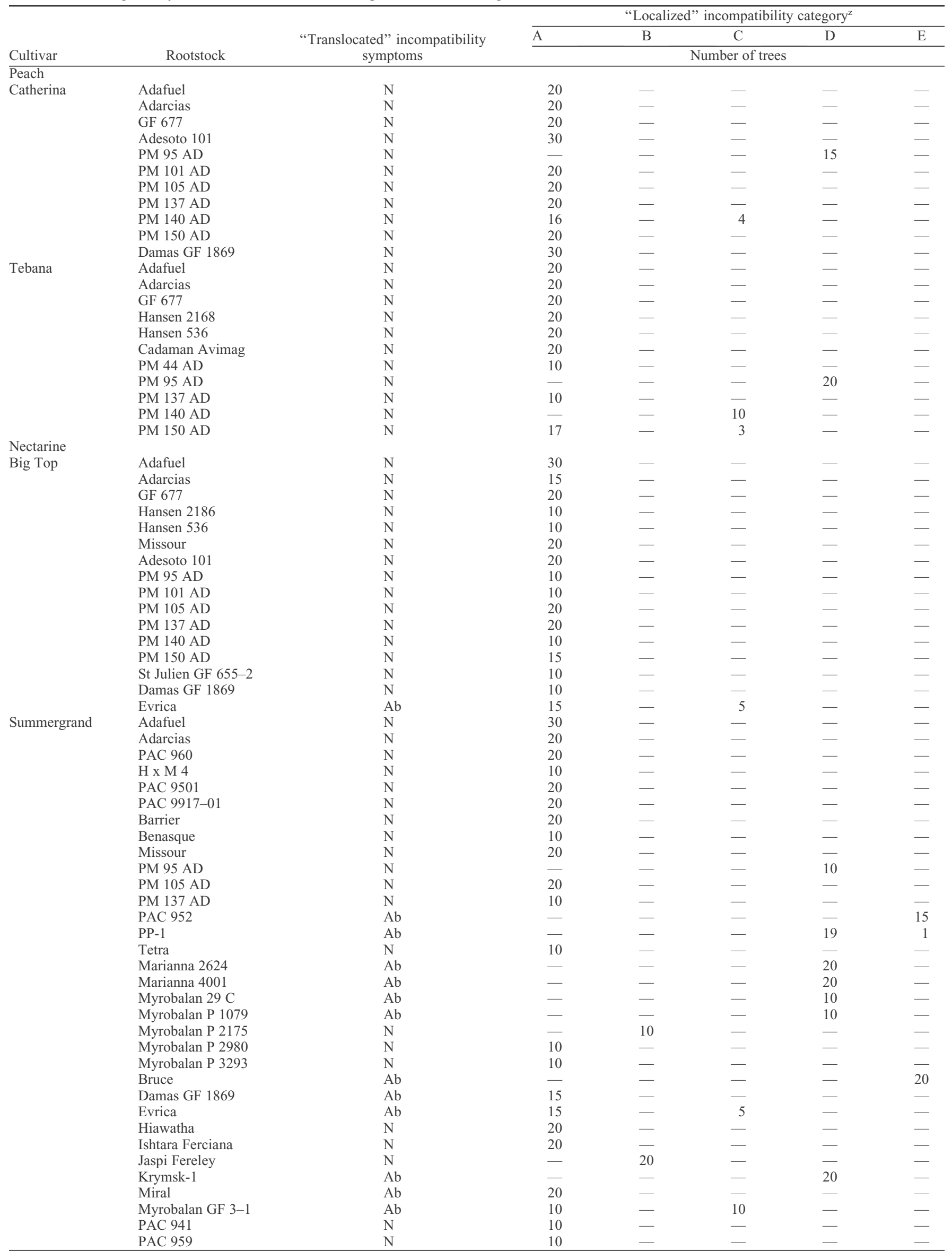

${ }^{2}$ Categories A, B, C, D, and E: classification of the rating of "localized" graft incompatibility according to Mosse and Herrero (1951).

$\mathrm{N}$, visual normal trees; $\mathrm{Ab}$, abnormal scion behavior, leaf yellowing, reduction in vigor. 


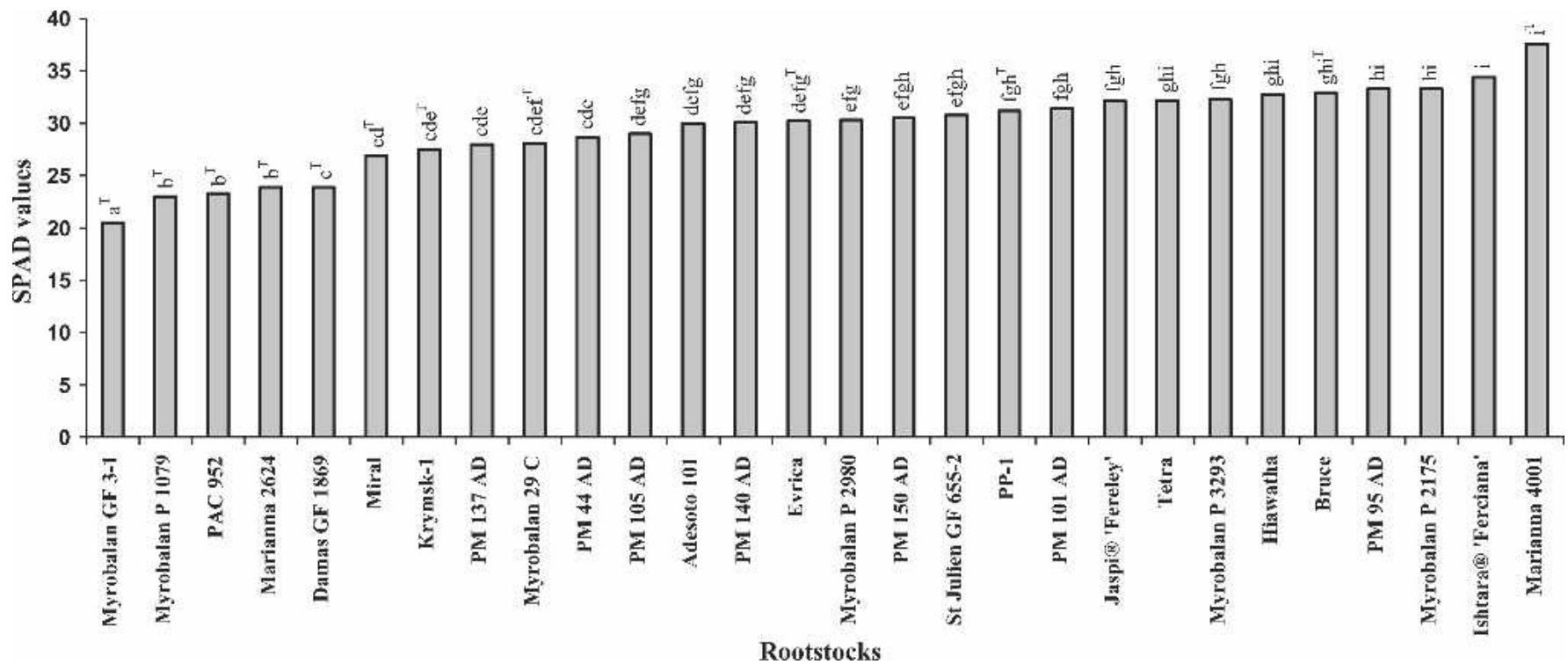

Fig. 1. SPAD values of 'Summergrand' nectarine cultivar grafted on different plum-based rootstocks. Mean separation within columns at $P \leq 0.05$. T"Translocated" incompatibility symptoms: abnormal scion behavior, leaf yellowing, and reduction in vigor.

'Summergrand' nectarine trees when they were grafted on PAC 952 and PP-1 (Table 2).

The stem diameter growth study (Table 3) indicates that "localized" incompatibility was not associated with a decrease in vegetative growth when dwarfing rootstocks were used. In fact, 2-year-old trees on Ishtara and Jaspi showed the lowest circumference below and above the graft union, but did not significantly differ from incompatible rootstocks like Marianna 4001, Bruce, and Krymsk-1. The same occurred in 3-year-old trees with Ishtara, which did not differ from trees grafted on Evrica rootstock. Belonging to the interspecific hybrid plum group, Ishtara and Jaspi rootstocks were compatible when they were grafted with 'Summergrand' nectarine (Table 2). This confirms previous investigations with other nectarines cultivars (Iglesias et al., 2004). However, despite having a homogeneous appearance, 'Summergrand'/Jaspi and 'Summergrand'/Ishtara trees were stunted (Table 3) as compared with other trees with compatible unions. These results support the potential use of Ishtara and Jaspi as dwarfing rootstocks for peach and nectarine cultivars (Loreti and Massai, 2002; Reighard et al., 2004). Nevertheless, results in terms of compatibility of Jaspi contrast with the report of De Salvador et al. (2002) in which an incompatible behavior of Jaspi with 'Suncrest' peach cultivar was observed. This suggests that this rootstock should be tested for longer time to assess its compatibility behavior with peach and nectarine cultivars.

\section{"Translocated" and "localized" incompatibilities relationship}

Some combinations showed the coexistence of two types of incompatibility (Table 2) as reported previously (Moreno et al., 1995a; Salesses and Bonnet, 1992). This has been observed in 'Summergrand' nectarine combinations grafted on PAC 952, PP-1, Marianna 4001, Myrobalan 29 C, Myrobalan

Table 3. Stem circumference $(\mathrm{mm})$ above and below $(\approx 5 \mathrm{~cm})$ the graft union in 'Summergrand' nectarine grafted on plum rootstocks.

\begin{tabular}{|c|c|c|c|c|}
\hline \multirow[b]{2}{*}{ Rootstock } & \multicolumn{2}{|c|}{ 2-year-old tree } & \multicolumn{2}{|c|}{ 3-year-old tree } \\
\hline & Above graft & Below graft & Above graft & Below graft \\
\hline$\overline{\mathrm{PM}} 95 \mathrm{AD}$ & $33.5 b^{L}$ & $34.3 b^{L}$ & - & - \\
\hline PM 105 AD & $32.0 \mathrm{~b}$ & $32.3 \mathrm{~b}$ & - & - \\
\hline PM 137 AD & $36.1 \mathrm{bc}$ & $39.1 \mathrm{bc}$ & - & - \\
\hline PP-1 & $33.3 \mathrm{~b}^{\mathrm{TL}}$ & $39.2 \mathrm{bc}{ }^{\mathrm{TL}}$ & - & - \\
\hline St Julien GF 655-2 & $40.6 \mathrm{bc}$ & $49.2 \mathrm{c}$ & - & - \\
\hline Tetra & $39.0 \mathrm{bc}$ & $45.8 \mathrm{c}$ & - & - \\
\hline Marianna 4001 & $40.4 \mathrm{bc}^{\mathrm{TL}}$ & $38.8 \mathrm{bc}{ }^{\mathrm{TL}}$ & - & - \\
\hline Myrobalan $29 \mathrm{C}$ & - & - & $20.0 \mathrm{~b}^{\mathrm{T}}$ & $31.0 \mathrm{~b}^{\mathrm{T}}$ \\
\hline Bruce & $36.6 \mathrm{bc}^{\mathrm{TL}}$ & $39.6 \mathrm{bc}^{\mathrm{TL}}$ & - & - \\
\hline Damas GF 1869 & $42.6 \mathrm{c}^{\mathrm{T}}$ & $39.4 \mathrm{bc}^{\mathrm{T}}$ & - & - \\
\hline Evrica & - & - & $25.1 \mathrm{bc}^{\mathrm{T}}$ & $35.8 \mathrm{~b}^{\mathrm{T}}$ \\
\hline Hiawatha & $44.4 \mathrm{c}$ & $48.5 \mathrm{c}$ & & \\
\hline Ishtara Ferciana & $30.0 \mathrm{~b}$ & $36.9 \mathrm{bc}$ & $32.5 \mathrm{c}$ & $39.7 \mathrm{~b}$ \\
\hline Jaspi Fereley & $23.8 \mathrm{a}$ & $29.0 \mathrm{ab}$ & - & - \\
\hline Krymsk-1 & $21.6 \mathrm{a}^{\mathrm{TL}}$ & $25.6 \mathrm{a}^{\mathrm{TL}}$ & - & - \\
\hline Miral & - & - & $22.9 \mathrm{~b}^{\mathrm{T}}$ & $25.5 \mathrm{a}^{\mathrm{T}}$ \\
\hline Myrobolan GF 3-1 & - & - & $13.5 \mathrm{a}^{\mathrm{TL}}$ & $24.2 \mathrm{a}^{\mathrm{TL}}$ \\
\hline
\end{tabular}

Mean separation within columns by Duncan's multiple range tests at $P \leq 0.05$.

T"Translocated” incompatibility symptoms: abnormal scion behavior, leaf yellowing, and reduction in vigor. L"Localized" incompatibility occurrence: cambial involution or/and vascular discontinuity at the graft union.

P 1079, Bruce, and Krymsk-1 (Table 2). These graft unions were classified as " $\mathrm{D}$ " and even "E" (smoothly broken unions) with severe bark anomalies and vascular discontinuities in the graft plane. 'Summergrand'/PP-1 combinations showed additionally weak swollen and broken unions. Concerning the group of slowgrowing plums, graft incompatibility was only found with PP-1 and PAC 952 (Tables 1 and 2 ). It could be that they hybridized with other plum species that were incompatible with peach and nectarine cultivars.

In this study, it was observed that in the case of coexistence of both incompatibilities, the "translocated" type preceded the occurrence of "localized" incompatibility. This may confirm that in peach/plum combinations, "localized" incompatibility could be the result of physiological anomalies at the graft union incited by "translocated" incompatibility. In fact, starch blockage above the graft union in the scion of incompatible grafts with "translocated" symptoms (Breen, 1975; Moing et al., 1987) may prevent cambium division (Oribe et al., 2003) at the graft interface and thereby impede vascular tissue development and successful connection. This may lead to the formation of discontinuities in the graft union interface (unpublished data).

According to Wertheim and Webster (2005), the trunk diameter above the graft union of most incompatible combinations is smaller than below it (Table 3). However, this difference was not significant in the present study. Nevertheless, a significant correlation was found between stem circumference above the graft union of 2-year-old ( $r=$ $-0.524, P \leq 0.01)$ and 3 -year-old trees $(r=$ $-0.238, P \leq 0.05)$ and both graft incompatibility types, which is in agreement with the results of Simard and Olivier (1999) for 
apricot. This correlation may be explained by the decrease of water and nutrient supply from roots as consequence of graft incompatibility, which involves the diminution or cease of vegetative growth of the scion and the development of the rootstock as an independent entity.

In summary, no incompatibility was found on Euamygdalus subgenus rootstocks with any of the peach varieties used in this investigation. This study provides evidence of the potential use of $P$. insititia species rootstocks for the peach industry. Results showed the possible implication of environmental conditions on the development of graft compatibility-incompatibility. This suggests the necessity of investigating genetic and environmental interactions in graft incompatibility phenomena in Prunus genus. SPAD values were useful to visually assess the rate of "translocated" graft incompatibility only in cases of severe incompatibility between scion-rootstock components.

It is concluded that further studies concerning the development of optimal scionrootstock combinations based on new plant material, especially plum rootstocks, including $P$. cerasifera and $P$. besseyi species, should be conducted before their commercial release as rootstocks for peach and nectarine cultivars.

\section{Literature Cited}

Breen, P.J. 1975. Effect of peach/plum graft incompatibility on seasonal carbohydrate changes. J. Amer. Soc. Hort. Sci. 100:253-259.

Crossa-Raynaud, M. and J.M. Audergon. 1987. Apricot rootstocks, p. 321-360. In: R.C. Rom and R.F. Carlson (eds.). Rootstocks for fruit crops. Wiley, New York.

De Salvador, F.R., G. Ondradu, and B. Scalas. 2002. Horticultural behaviour of different species and hybrids as rootstocks for peach. Acta Hort. 592:317-322.

Errea, P. 2001. Early detection of graft incompatibility in apricot (Prunus armeniaca) using in vitro techniques. Physiol. Plant. 112:135-145.

FAOSTAT. 2006. FAO statistical databases. http:// faostat.fao.org/.

Gomez Aparisi, J., M. Carrera, A. Felipe, and R. Socias i Company. 2001. 'Garnem', 'Monegro' y 'Felinem': Nuevos patrones hibridos almendo $\mathrm{x}$ melocotonero resistentes a nematodos y de hoja roja para frutales de hueso. ITEA $97(\mathrm{~V}) 3$ 282-288.

Gur, A., R.M. Samish, and E. Lifshitz. 1968. The role of the cyanogenic glycoside on the quince in the incompatibility between pear cultivars and quince rootstocks. Hort. Res. 8:113-134.

Herrero, J. 1951. Studies of compatible and incompatible graft combinations with special reference to hardy fruit trees. J. Hort. Sci. 26:186-237.

Iglesias, I., R. Monserrat, J. Carbó, J. Bonany, and M. Casals. 2004. Evaluation of agronomical performance of several peach rootstocks in Lleida and Girona (Catalonia, Spain). Acta Hort. 658:341-348.

Jänes, H. and A. Pae. 2004. Evaluation of nine sweet cherry clonal rootstocks and one seedling rootstock. Agron. Res. 2:23-27.

Layne, R.E.C. 1987. Peach rootstocks, p. 185-216. In: R.C. Rom and R.F. Carlson (eds.). Rootstocks for Fruit Crops. Wiley, New York.

Loreti, F. and R. Massai. 2002. The high density peach planting system: Present status and perspectives. Acta Hort. 592:377-390.

Moing, A. and G. Salesses. 1988. Peach/plum graft incompatibility: structural, physiological and genetic aspects. Acta Hort. 227:177-186.

Moing, A., G. Salesses, and P.H. Saglio. 1987. Growth and the composition and transport of carbohydrate in compatible and incompatible peach/plum grafts. Tree Physiol. 3:345-354.

Moing, A. and J.P. Gaudillère. 1992. Carbon and nitrogen partitioning in peach/plum grafts. Tree Physiol. 10:81-92.

Moing, A. and P. Carde. 1988. Growth, cambial activity and phloem structure in compatible and incompatible peach/plum grafts. Tree Physiol. 4:347-359.

Moreno, M.A., A. Moing, M. Lansac, J.P. Gaudillère, and G. Salesses. 1993. Peach/Myrobalan plum graft incompatibility in the nursery. J. Hort. Sci. 68:705-714.

Moreno, M.A., J.P. Gaudillère, and A. Moing. 1994. Protein and amino acid content in compatible and incompatible peach/plum grafts. J. Hort. Sci. 69:955-962.

Moreno, M.A., M.C. Tabuenca, and R. Cambra. 1995a. Adara: A plum rootstock for cherries and other stone fruit species. HortScience 30:1316-1317.

Moreno, M.A., M.C. Tabuenca, and R. Cambra. 1995b. Adesoto 101: A plum rootstock for peach and other stone fruit species. HortScience 30:1314-1315.

Mosse, B. 1962. Graft-incompatibility in fruit trees. Tech. Commun. Bur. Hort. E. Malling. 28:36 p.

Mosse, B. and J. Herrero. 1951. Studies on incompatibility between some pear and quince grafts. J. Hort. Sci. 26:238-245.

Nasr, T.A., E.M. El-Azab, and M.Y. El-Shurafa. 1977. Effect of salinity and water table on growth and tolerance of plum and peach. Scientia Hort. 7:225-235.

Nicotra, A. and L. Moser. 1997. Two new rootstocks for peach and nectarines. Penta and Tetra. Acta Hort. 451:269-271.

Okie, W.R. 1987. Plum rootstocks, p. 321-360. In: R.C. Rom and R.F. Carlson (eds.). Rootstocks for fruit crops. Wiley. New York.

Oribe, Y., R. Funada, and T. Kubo. 2003. Relationships between cambial activity, cell differentiation and the localization of starch in storage tissues around the cambium in locally heated stems of Abies sachalinensis (Schmidt) Masters. Trees (Berl.) 17:185-192.

Pina, A. and P. Errea. 2005. A review of new advances in mechanism of graft compatibilityincompatibility. Scientia Hort. 106:1-11.

Pinochet, J., C. Calvet, A. Hernández-Dórrego, A. Bonet, A. Felipe, and M.A. Moreno. 1999.
Resistance of peach and plum rootstocks from Spain, France, and Italy to root-knot nematode Meloidogyne javanica. HortScience 34: 1259-1262.

Reighard, G., R. Andersen, J. Anderson, W. Autio, T. Beckman, T. Baker, R. Belding, G. Brown, P. Byers, W. Cowgill, D. Deyton, E. Durner, A. Erb, D. Ferree, A. Gaus, R. Godin, R. Hayden, P. Hirst, S. Kadir, M. Kaps, H. Larsen, T. Lindstrom, N. Miles, F. Morrison, S. Myers, D. Ouellette, C. Rom, W. Shane, B. Taylor, K. Taylor, C. Walsh, and M. Warmund. 2004 Growth and yield of Redhaven peach on 19 rootstocks at 20 North American locations. J. Amer. Pom. Soc. 58:174-202.

Reighard, G.L., D.R. Ouellette, and K.H. Brock. 2005. Survival, growth and yield for Carogem peach on an interstem and dwarfing rootstocks. Sixth international peach congress. ISHS, Chile. Abstract book

Reighard, G.L., W.C. Newall, Jr., E.I. Zehr, T.G Beckman, W.R. Okie, and A.P. Nyczepir 1997. Field performance of Prunus rootstock cultivars and selections on replant soils in South Carolina. Acta Hort. 451:243-249.

Salesses, G. and A. Bonnet. 1992. Some physiological and genetic aspects of peach/plum graft incompatibility. Acta Hort. 315:177 186

Shi, Y. and D.H. Byrne. 1995. Tolerance of Prunus rootstocks to potassium carbonate-induced chlorosis. J. Amer. Soc. Hort. Sci. 120:283285

Simard, M.H. and G. Olivier. 1999. Julior-Ferdor et variétés d'abricotier. L'arboriculture Fruitière 523:39-42.

Socias i Company, R., J. Gómez Aparisi, and A. Felipe. 1995. A genetical approach to iron chlorosis in deciduous fruit trees, p. 167-174. In: J. Abadía (ed.). Iron nutrition in soil and plants. Kluwer Academic Publishers, Dordrecht, The Netherlands.

Treutter, D. and W. Feucht. 1991. Accumulation of phenolic compounds above the graft union of cherry trees. Gartenbauwissenschaft 56 : 134-137.

Weibel, A., R.S. Johnson, and T.M. DeJong. 2003 Comparative vegetative growth responses of two peach cultivars grown on size-controlling versus standard rootstocks. J. Amer. Soc. Hort. Sci. 128:463-471

Wertheim, S.J. and A.D. Webster. 2005. Rootstocks and interstems, p. 156-175. In: J. Tromp, A.D. Webster and S.J. Wertheim (eds.). Fundamentals of temperate zone tree fruit production. Backhuys Publishers, Leiden, Netherlands.

Yamaguchi, M., T. Haji, H. Yaegaki, and M. Nakano. 2004. Screening of graft-compatibility between 'Akatsuki' and several interstocks of related species and interspecific hybrids grafted on peach seedlings. Bul. Natl. Inst. Fruit Tree Sci. 3:67-76.

Zarrouk, O., Y. Gogorcena, J. Gómez-Aparisi, J.A. Betrán, and M.A. Moreno. 2005. Influence of almond $\mathrm{x}$ peach hybrids rootstocks on flower and leaf mineral concentration, yield and vigour of two peach cultivars. Scientia Hort $106: 502-514$ 